V. Chumack, Cand. Sc. (Eng.), Assoc. ORCID 0000-0001-8401-7931

M. Kovalenko, Cand. Sc. (Eng.), Assoc. ORCID 0000-0002-5602-2001

I. Tkachuk, Msc. ORCID 0000-0002-5717-2458

National Technical University of Ukraine "Igor Sikorsky Kyiv Polytechnic Institute"

\title{
MATHEMATICAL SIMULATION OF A LINEAR INDUCTION MOTOR FOR COLOR METALS SEPARATION
}

\begin{abstract}
Non-ferrous and metal scrap separation nowadays is becoming more and more actual problem. There are several traditional methods of separating ferrous and non-ferrous metal waste. To automate this process, it is necessary to use mechanized systems based on linear induction motors. This paper is presented to the study of such type object. In this paper several field mathematical models have been developed, which are implemented by the finite element method in Comsol Multiphysics software package. The object of the study is a linear three-phase induction motor which is constructed for the non-ferrous metal scrap separation. With the help of the developed mathematical model the basic parameters and characteristics of a linear motor are calculated and the optimal limits of its operation are determined and the minimum configuration of the scrap is required for its reliable separation. A series of calculations was performed to determine the optimal operating modes of the linear separator and to formulate recommendations for the practical implementation of the experimental one. In this paper relation between electrical conductivity and force was calculated. It was performed due to optimal practical recommendations, which are used in real life operation.
\end{abstract}

Keywords: scrap, separator, linear three-phase induction motor, mathematical modeling, industry waste, non-ferrous metals, technical measures.

\section{References}

1. METALURHIYA KOL'OROVYKH METALIV (METALLURGY OF COLOR METALS) / Bredykhin V.M., Smyrnov V.O., Poruchyv V.I, etc.]. - Zaporizhzhya: Zaporiz'ka derzhavna inzhenerna akademiya, 2009. - $452 \mathrm{p}$.

2. INDUCTION MACHINES FOR ELECTRODYNAMIC SEPARATION OF NON-FERROUS METALS / A.Yu. Konyayev, S.L.Nazarov. // Faculty of Electrical Engineering, Ural Federal University. - 2016. - p. $13-14$.

3. Matematychne modelyuvannya elektrychnykh mashyn $\mathrm{z}$ postiynymy mahnitamy (Mathematical modeling of electric machines with constant magnet) / KOVALENKO M.A., VAS'KOVS'KYY YU.M., HAYDENKO YU.A.. // National Technical University of Ukraine. - 2017. - p. 193.

4. MATEMATYCHESKOE MODELYROVANYE ÉLEKTROMAHNYTNYKH MUFT (MATHEMATICAL MODELING OF ELECTROMAGNETIC COUPLANG) / MA Kovalenko, YV Malyar. // Mizhnarodnyy naukovo-tekhnichnyy zhurnal" Suchasni problemy elektroenerhotekhniky ta avtomatyky". - 2017. - p. 351-352.

Надійшла 23.08.2019

Received 23.08.2019

УДК 621.311.42

О.В. Сподинський, інженер Інститут електродинаміки Національної академії наук України А.В. Зайченко, магістрант Національний технічний університет України «Київський політехнічний інститут імені Ігоря Сікорського»

\section{ВПРОВАДЖЕННЯ ПРОТИАВАРІЙНОЇ АВТОМАТИКИ МЕРЕЖІ 110-150 КВ ПІВДЕННОЇ ЕС, ЯК ЗАСОБУ ДЛЯ ПІДВИЩЕННЯ НАДІЙНОСТІ ЕЛЕКТРОПОСТАЧАННЯ СПОЖИВАЧІВ}

У статті розглянуто питання підвищення надійності електропостачання споживачів, шляхом впровадження протиаварійної автоматики, у енергодифіциттнх районах південно західної частини Південної енергосистеми. Описано комплекс технічних заходів та перелік об'єктів, необхідних для реалізачї̈ протиаварійної автоматики. Сформовано основні технічні вимоги та функиії, які необхідні для (C) О.В. Сподинський, А.В. Зайченко , 2019 
підвищення надійності електропостачання споживачів.

Ключові слова: підстанція, протиаварійна автоматика, енергосистема, електропостачання, добовий графік навантаження.

Основним генеруючим джерелом Південної енергосистеми (ЕС) є Південноукраїнська атомна електростанція (AЕC), яка забезпечує електропостачання споживачів центральних та, частково східних районів енергосистеми, потреба в потужності яких також може бути забезпечена за рахунок отримання електроенергії від Каховської ГЕС або з надлишкової Дніпровської ЕС, а саме від Криворізької та Запорізької теплової електростанції (ТЕС).

Найбільш проблематичним є забезпечення стабільного електропостачання споживачів південнозахідної частини енергосистеми, а саме Одеський та Арцизький енергорайони, де розташовані підстанції (ПС) 330 кВ Ново-Одеська, ПС 330 кВ Усатове та ПС 330 кВ Арциз.

Саме в цьому регіоні зосереджена більшість збудованих в Південній ЕС сонячних електростанцій та тих,

що планується побудувати найближчим часом загальною потужністю близько 324 МВт (у 2020 р. - понад 950

МВт). Планується також введення значного обсягу потужності на ВЕС поблизу ПС 330 кВ Трихати, 330 кВ Ново-Одеська та ПС 330 кВ Миколаїв (у 2020 р. планується ввести близько 2000 МВт). На жаль, нового електромережевого будівництва системного значення власниками ні ВЕС, ні СЕС не заплановано $[1]$.

Тому перспективи щодо забезпечення споживачів південних регіонів енергією відновлюваних джерел стримується, перш за все, пропускною спроможністю внутрішніх електричних мереж та можливостями регулювання добового балансу потужності у випадках непрогнозованого суттєвого зменшення (збільшення) потужності ВЕС чи СЕС через погодні умови.

Стан електричної мережі південно-західної частини Одеської області (Арцизький енерговузол) характеризується вкрай низькою надійністю електропостачання споживачів, яка визначається такими основними фактами [3]:

- відсутність власних базисних та маневрених генеруючих потужностей;

- відсутність резервного живлення ПС 330 кВ Арциз по напрузі 330 кВ від мережі ОЕС України (підстанція з'єднана однією ПЛ 330 кВ з електричними мережами суміжної енергосистеми - з ВРУ 330 кВ Молдавської ДРЕС);

- значне зношення ПЛ та обладнання, яке експлуатується на підстанціях;

- слабкі протяжні зв'язки 110 кВ з опорними підстанціями 330 кВ Одеського енерговузла;

- ускладнене здійснення ремонтів ряду ПЛ 110 кВ, траси яких проходять територією суміжної держави, в тому числі ПЛ Молдавська ДРЕС - ПС 110 кВ Старокозаче.

Проблема дефіцитних за генеруючими потужностями південно-західних районів Південної ЕС залишається й за умови необхідності забезпечення видачі потужності від нових електростанцій на відновлювальних джерелах енергії (ВДЕ). Ці обставини можуть привести до розвитку непередбачуваних аварійних ситуацій в електричних мережах регіону.

Тому для часткового вирішення проблем надійності електропостачання споживачів в південнозахідних районах Південної ЕС було впроваджено комплекс протиаварійної автоматики (ПА) південнозахідних районів Південної ЕС.

Комплекс ПА впроваджений для забезпечення надійного енергопостачання відповідальних споживачів регіону:

- при відключенні живильних зв'язків й аварійному дефіциті активної й реактивної потужності викликаному аварійним відключенням ПЛ;

- при зниженні генерації відновлюваними джерелами енергії в ремонтних режимах живильних ПЛ.

Протиаварійне керування виконується за рахунок керування джерелами активної й реактивної потужності й дозованого відключення менш відповідальних споживачів на об'єктах регіону.

Основна мета створення комплексу ПА:

- підвищення надійності та ефективності роботи об'єднаної енергосистеми (ОЕС) України;

- своєчасне надання оперативному персоналу енергосистеми та ОЕС достовірної інформації в режимі плинного часу про хід технологічного процесу, стан контролюючого енергорайону та комплексу ПА;

- забезпечення персоналу ретроспективною технологічною інформацією (реєстрація подій, розрахунок показників) для аналізу, оптимізації та планування роботи енергорайону та його ремонту;

- підвищення довговічності, ступеня експлуатаційної надійності обладнання.

- зменшення збитків від помилок персоналу.

До складу комплексу ПА входить:

- центральний комплект протиаварійної автоматики (ЦКПА) на ПС 330 кВ;

- периферійні комплекти протиаварійної автоматики (ПКПА) на віддалених підстанціях. 
На підстанціях, контрольованих ПКПА, встановлюються (див. табл.1):

- основна периферійна шафа протиаварійної автоматики (ПШПА);

- дублююча периферійна шафа протиаварійної автоматики;

- шафа вимірів (ШВ);

- шафа збору інформації та резервування вимірів (ШЗІРВ);

- засоби синхронізації часу.

Таблиця 1. Перелік підстанцій з контрольованими ПКПА.

\begin{tabular}{|l|c|c|c|c|}
\hline Назва підстанції & $\begin{array}{c}\text { Основн } \\
\text { а ПШПА }\end{array}$ & $\begin{array}{c}\text { Резервна } \\
\text { ПШПА }\end{array}$ & ШВ & ШЗІРВ \\
\hline ПС 330 кВ Арциз & + & + & + & + \\
\hline ПС 110 кВ Болград & + & + & + & + \\
\hline ПС 110 кВ Рені & + & + & + & + \\
\hline ПС 110 кВ & + & + & + & + \\
\hline ПС 110 кВ Еталон & + & + & + & + \\
\hline ПС 110 кВ Ізмаїл & + & + & + & + \\
\hline ПС 110 кВ Кілія & + & + & + & + \\
\hline ПС 110 кВ Ст. & + & + & + & + \\
\hline ПС 110 кВ Коса & + & & + \\
\hline ПС 110 кВ Арциз & & & + & + \\
\hline
\end{tabular}

На ПС 330 кВ Арциз встановлюється ЦКПА, до якого належать:

- основна шафа сервера комплексу ПА;

- резервна шафа сервера комплексу ПА;

- шафа сервера збору інформації;

- комунікаційна стійка;

- автоматизовані робочі місця (АРМ).

Таблиця 2. Перелік об’єктів відключення навантаження

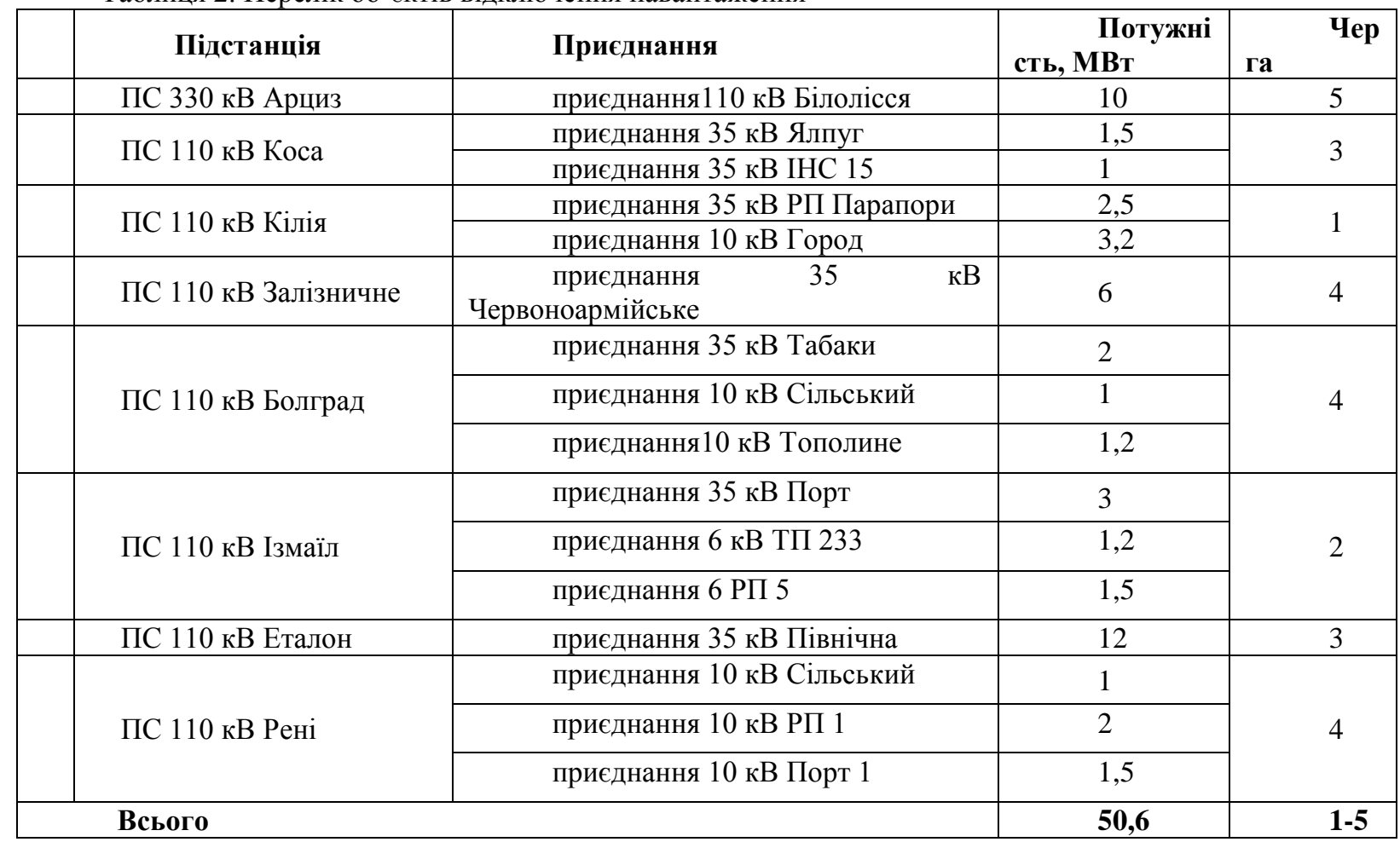

Передача значень контрольованих параметрів та команд ПА виконується по існуючих ВЧ трактах по ПЛ 110 кВ та по волоконно-оптичних каналах. У якості резервного каналу передачі даних використовується обладнання GSM модемів по стандарту 3G. 
Комплекс ПА функціонує безперервно, а саме здійснює безперервний збір та обробку технологічної інформації, відображає на мнемосхемах АРМ диспетчера поточний стан об'єктів, підключених до комплексу, і параметрів їх режимів. Робота комплексу ПА полягає у тому, що при отримані на локальному рівні сигналу на відключення навантаження від централізованого комплексу ПА виконується відключення навантаження з контролем потужності вимкненого навантаження та рівнів напруги в післяаварійному режимі. Якщо, після відключення навантаження, напруга на секціях шин ПС значно збільшується, то локальною частину комплексу ПА, розташованому безпосередньо на об'єкті з урахуванням величин фактично вимкненого навантаження та напруги може бути реалізовано функцію дозованого автоматизованого ввімкнення навантаження. Такий підхід зменшує кількість необгрунтованих відключень електропостачання споживачів [2].

В табл. 2 наведено перелік об’єктів відключення навантаження та їх розподіл по чергам.

Отже, впровадження комплексу ПА підвищує надійність електропостачання споживачів за рахунок дозованої дії на відключення навантаження при виникненні коливань потужності в мережі, що в свою чергу полегшує регулювання добового графіку навантаження ЕС.

\section{Список використаної літератури}

1. Звіт з оцінки відповідності (достатності) генеруючих потужностей (доопрацьований) / НЕК «Укренерго» 2018p.

2. Технічне завдання на розробку комплексу протиаварійної автоматики мережі 110-150 кВ Південної ЕС / НЕК «Укренерго» 2016р.

3. Лінник О.М., Кануннікова Р.С., Проблеми впровадження вітрових та сонячних електростанцій на території Південної енергосистеми та вплив їх роботи на режими об'єднаної енергосистеми / Інформаційний збірник «Промислова електроенергетика та електротехніка» 2015p.

Надійшла 21.07.2019

Received 21.07.2019 